YEARBOOK

of ANTITRUST

and REGULATORY

STUDIES

www.yars.wz.uw.edu.pl
Peer-reviewed scientific periodical, focusing on legal and economic issues of antitrust and regulation.

Creative Commons Attribution-No Derivative Works 3.0 Poland License.

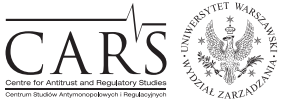

Centre for Antitrust and Regulatory Studies, University of Warsaw, Faculty of Management www.cars.wZ.uw.edu.pl

\title{
Extending the Principle of Economic Continuity to Private Enforcement of Competition Law. What Lies Ahead for Corporate Restructuring and Civil Damages Proceedings after Skanska?
}

Case Comment to the Judgement of the Court of Justice of 14 March 2019 Skanska Industrial Solutions and others (Case C-724/17)

by

Vasiliki Fasoula* $^{*}$

\section{CONTENTS}

I. Introduction

II. Facts of the case

III. Comments

IV. Conclusion

\section{Abstract}

In the tradition of civil law Member States, civil liability issues are linked to the legal entity that caused a damage, with the exception of lifting the corporate veil. The Finnish competition authority imposed fines to Finnish companies that participated in an asphalt cartel. Following that decision, an action for damages was lodged for infringement of Article 101 TFEU that ultimately led to the Skanska ruling. The European judge completes and specifies some ambiguities of the Damages Directive. From a holistic point of view of the objective pursued by both public and private enforcement of European competition law rules, the economic entity of an 'undertaking', as it is defined by European law rather than the legal entity as it is defined by national law, must be a substantive criterion, and not a procedural one, in civil liability procedures before national courts awarding damages for European law infringements. Introducing the principle of economic continuity to national

* PhD candidate, Paris II Panthéon-Assas University, Paris, France; ATER in Private Law, Paris Nanterre University, Paris, France, e-mail: vicky_fasoula@hotmail.com. Article received: 8 June 2019; accepted: 16 September 2019. 
civil liability procedures is a creeping harmonisation of national civil law in order to serve the effectiveness of European competition law. The scope of Skanska could also extent to Article 102 TFEU infringements. Corporate restructuring must follow from now on a lengthy and complex due diligence as the acquirers could be liable for their predecessors' infringements in any Member State.

\section{Résumé}

Dans la tradition des États membres de droit civil, les questions de responsabilité civile sont liées à la personne morale qui a causé un dommage, à l'exception du voile corporatif. L'autorité finlandaise de la concurrence a infligé des amendes aux entreprises finlandaises qui ont participé à une entente sur l'asphalte. Depuis cette décision, une action en dommages-intérêts a été introduite pour violation de l'article 101 du TFUE, qui a finalement abouti à l'arrêt Skanska. Le juge européen complète et précise certaines ambiguïtés de la directive Dommages et intérêts. D'un point de vue global de l'objectif poursuivi par l'application publique et privée des règles du droit européen de la concurrence, l'entité économique de l' «entreprise» telle qu'elle est définie par le droit européen, et non l'entité juridique telle qu'elle est définie par le droit national, doit être un critère de fond, et non de procédure, dans les procédures en responsabilité civile devant les juridictions nationales qui accordent des indemnités pour violation du droit européen. Lintroduction du principe de continuité économique dans les procédures nationales de responsabilité civile est une harmonisation progressive du droit civil national afin de servir l'efficacité du droit européen de la concurrence. Le champ d'application de Skanska pourrait également s'étendre aux infractions à l'article 102 du TFUE. La restructuration des entreprises doit dorénavant faire l'objet d'un contrôle préalable long et complexe, car les acquéreurs pourraient être fiables pour les infractions commises par leurs prédécesseurs dans tous les États membres.

Key words: actions for damages, determination of the entities liable to provide compensation, principle of economic continuity, autonomous concept of undertaking, effectiveness of EU competition law.

JEL: K21

\section{Introduction}

The Court of Justice of the European Union's (hereinafter: CJEU) preliminary ruling in $S k a n s k a^{1}$ follows the line of its previous case law regarding

1 Judgement of the Court of 14.03.2019, Case C-724/17 Vantaan kaupunki v Skanska Industrial Solutions Oy, NCC Industry Oy, Asfaltmix Oy, ECLI:EU:C:2019:204. 
the private enforcement of competition law (Iannuccelli 2014, p. 223-240). However, it can be considered to be a landmark case, as it goes a step further in addressing some questions left unanswered by Directive 2014/104/EU of the European Parliament and of the Council of 26 November 2014 on certain rules governing actions for damages under national law for infringements of the competition law provisions of the Member States and of the European Union (hereinafter: Directive 2014/104/EU) ${ }^{2}$, mainly the determination of the entities that are liable under civil law for compensation in actions for damages for breach of Article 101 of the Treaty of Functioning of the European Union (hereinafter: TFEU) before national civil courts. The CJEU adopts a holistic view of the EU competition law enforcement system in the internal market. Under the point of view of such a coherent system, both public enforcement of competition rules by national competition authorities (hereinafter: NCAs) of Member States and private enforcement of those same rules under national civil liability proceedings have a complementary role in preserving the effectiveness of European Union's (hereinafter: EU) competition law provisions, by punishing anticompetitive behaviour on the part of the undertakings as well as deterring them from engaging in such conduct. For that reason, it is a matter of European, and not national law, to determine the entities liable to pay damages for EU competition law infringements. By ruling so, the CJEU introduces the autonomous concept of 'undertaking' to civil liability actions before national courts of the Member States, and extents the application of the principle of economic continuity, previously used when imposing fines for EU competition law infringement, to private enforcement of EU competition law rules as well.

\section{Facts of the case}

The facts of the ruling are based on the asphalt cartel in Finland between 1994 and 2002. The companies involved in dividing up contracts, prices and tendering for contracts included, among others, Lemminkäinen Oyj, Sata-Asfaltti Oy, Interasfaltti Oy, Asfalttineliö Oy and Asfaltti-Tekra Oy. Since the beginning of their participation in the asphalt cartel, a lot of corporate restructuring took place involving the above mentioned undertakings: Asfaltti-Tekra changed its name to Skanska Asfaltti Oy and acquired all the shares in Sata-Asfaltti on 2000. The latter was wound up due to a voluntary

2 Directive 2014/104/EU of the European Parliament and of the Council of 26.11.2014 on certain rules governing actions for damages under national law for infringements of the competition law provisions of the Member States and of the European Union, OJ L 349, 5.12.2014, p. 1-19. 
liquidation procedure in January 2002 and in August 2017 Sata-Asfaltti changed its name to Skanska Industrial Solutions (SIS). In October 2000, NCC Finland Oy acquired the shares in Oy Läntinen Teollisuuskatu, the parent company of Interasfaltti. On 2002, Interasfaltti and Läntinen merged and became Interasfaltti. One year later, NCC Finland Oy split into three new companies, including NCC Roads Oy which owned all the shares in Interasfaltti. Finally, in December 2003, Interasfaltti was wound up due to a voluntary liquidation procedure and its commercial activities were transferred to NCC Roads. In May 2006, that company changed its name to NCC Industry (NCC). In 2000, Siilin Sora Oy, changed its name to Rudus Asfaltti Oy and acquired all the shares in Asfalttineliö. The latter was wound up due to a voluntary liquidation insolvency procedure and its commercial activities were transferred to Rudus Asfaltti, which changed its name to Asfaltmix in 2014.

Following the Finnish Competition Authority's (Kilpailuvirasto) proposition of 31 March 2004 to impose fines onto the companies that participated in the cartel, the Finnish Supreme Administrative Court (Korkein hallinto-oikeus), in accordance with the economic continuity test recognised by the CJEU case law ${ }^{3}$, imposed fines on the cartel participants, including on SIS for its own conduct and that of Sata-Asfaltti, on NCC for the conduct of Interasfaltti and on Asfaltmix for the conduct of Asfalttineliö. On the basis of the decision imposing fines, the City of Vantaa that had concluded contracts with those companies during the time period when they were participating in the asphalt cartel, lodged, subsequently, an action for damages against the cartelists, including SIS, NCC and Asfaltmix before the Finnish District Court (Käräjäoikeus). The District Court ordered the above mentioned companies to compensate the City of Vantaa for the harm it suffered because of their anti-competitive conduct and also of the conduct of the companies whose commercial activities they had acquired and continued. The District Court's reasoning was that 'in order to ensure the effectiveness of Article 101 TFEU, the economic continuity test must be applied to the determination of liability for damages in the same way as that for the imposition of fines ${ }^{4}$.'

Contrary to the District Court's decision, the Finnish Court of Appeal (Hovioikeus) dismissed the City of Vantaa's claims against SIS, on account of Sata-Asfaltti's conduct and NCC and Asfaltmix. The Court of Appeal refused the application of the economic continuity test to actions for damages due to the absence of detailed rules or more specific provisions in the national legal order - according to which only the legal entity that caused the damage may be held liable - and it also held that the principle of effectiveness of EU

3 Judgment of the Court of 18.12.2014, Case C-434/13 P European Commission v Parker Hannifin Manufacturing Srl and Parker-Hannifin Corp., ECLI:EU:C:2014:2456.

4 Case C-724/17 Vantaan kaupunki..., para 12. 
competition law cannot call into question the fundamental characteristics of the Finnish rules on civil liability ${ }^{5}$. After that, the City of Vantaa lodged an appeal before the Finnish Supreme Court (Korkein oikeus) that was faced with the following legal problem: on the one hand, the Finnish provisions on civil liability are founded on the principle that only the legal entity that caused the damage is liable. A derogation from this basic rule is possible, in Finland as in many other Member States, for legal entities belonging to a group of companies, by lifting the corporate veil if the entities concerned used the group structure in a reprehensible or artificial manner, in order to avoid legal liability issues (Cortese 2014, p. 73-93). On the other hand, CJEU case law allows any person to claim damages for the infringement of EU competition law if there is a causal link between the damage and the infringement. The national legal order of the Member States is responsible for the specific rules guarantying the exercise of that right. However, there is no clarification regarding the person that may be held liable to provide compensation for damages resulting from an infringement of Article 101 TFEU. If that determination is founded on the direct application of Article 101 TFEU, then the liability of the 'undertaking' may take place and according to the case law it may be attributed to the entity that has continued the business of the entity responsible for the infringement in question, if the latter has ceased to exist. If the person liable is not, however, determined by a direct application of Article 101 TFEU, then the Supreme Court must attribute liability for the damage caused by the asphalt cartel according to the rules of Finnish law and the principle of effectiveness of EU law. Confronted with this legal dilemma, the Supreme Court stayed the proceedings and referred those questionings to the CJEU for a preliminary ruling ${ }^{6}$.

The CJEU held that the determination of the entities liable for compensation in an action for damages for an infringement of Article 101 TFEU is done in accordance with EU law. Therefore, the concept of 'undertaking' under Article 101 TFEU must 'designate the perpetrator of an infringement' of Article 101 TFEU that 'must answer for the damage caused by the infringement'. Furthermore, since in the view of the CJEU, actions for damages form an 'integral part of the system for enforcement of those rules' and pursue the same objective of punishing Article 101 TFEU infringements and of deterrence, the principle of economic continuity applied to public enforcement of EU competition law provisions imposing fines must also be extended to the private enforcement of those rules, despite any restructuring or organisational change of the undertakings in order to escape liability. Finally, the effect of the ruling cannot be limited in time since the applicant

\footnotetext{
5 Case C-724/17, Vantaan kaupunki..., para 13.

${ }^{6}$ Ibidem, para 22.
} 
did not provide sufficient evidence that the entities concerned acted in good faith.

\section{Comments}

As established by consistent CJEU case law ${ }^{7}$, Article 101 and Article 102 TFEU produce direct legal effects in relations between individuals, creating directly rights for them which have to be protected by national courts, including the right for individuals to lodge claims for damages due to EU competition law infringements (Sauter 2016, p. 23). In Kone ${ }^{8}$, the CJEU clarified further that among the conditions necessary for a legal or physical person to claim compensation is the causal link between the harm suffered by the person due to an agreement or practice prohibited under Article 101 TFEU. In the same judgement, the CJEU held that a national provision on a causal link preventing actions for damages for umbrella pricing was contrary to EU competition law and therefore prohibited under Article 101 TFEU.

According to the principle of procedural autonomy of the Member States, that was introduced in 1976 by the landmark case Rewe $e^{9}$ and confirmed by consistent case law ${ }^{10}$, in the absence of EU rules governing the matter at hand, it is for the domestic legal system of each Member State to designate the courts having jurisdiction and to determine the procedural conditions governing actions at law intended to ensure the protection of rights which citizens have from the direct effect of Community law. In the case of actions for damages, Member States lay down the rules on the exercise of the right to claim compensation for harm resulting from an agreement or a conduct prohibited under Article 101 TFEU, provided that the principles of equivalence and effectiveness are guaranteed. The principle of equivalence guarantees that the national rules are applied without distinction, whether the alleged

7 Judgment of the Court of 13.06.2006, Case C-295/04 Vincenzo Manfredi v Lloyd Adriatico Assicurazioni SpA (C-295/04), Antonio Cannito v Fondiaria Sai SpA (C-296/04) and Nicolò Tricarico (C-297/04) and Pasqualina Murgolo (C-298/04) v Assitalia SpA., ECLI:EU:C:2006:461; judgement of the Court of 20.09.2001, Case C-453/99 Courage Ltd v Bernard Crehan and Bernard Crehan v Courage Ltd and Others, ECLI:EU:C:2001:465.

8 Judgment of the Court of 05.06.2014, Case C-557/12 Kone AG and Others v ÖBB-Infrastruktur AG, ECLI:EU:C:2014:1317, para 22.

9 Judgment of the Court of 16.12.1976, Case 33/76, Rewe-Zentralfinanz eG and Rewe-Zentral AG v Landwirtschaftskammer für das Saarland, ECLI:EU:C:1976:188.

10 Judgment of the Court of 15.03.2017, Case C-3/16, Lucio Cesare Aquino v Belgische Staat, ECLI:EU:C:2017:209; judgement of the Court of 19.10.2017, Case C-425/16, Hansruedi Raimund v Michaela Aigner, ECLI:EU:C:2017:776. 
infringement is of EU law or national law, where the purpose and cause of action are similar ${ }^{11}$. Complementary to that, the principle of effectiveness safeguards that the conditions laid down by the domestic norms do not make it impossible in practice to exercise the rights which the national courts are obliged to protect (Wilman 2015, p. 24).

The question raised in Skanska is to examine whether the determination of the entities liable to pay compensation for an infringement of Article 101 TFEU constitutes a condition of the right to claim damages or a rule regarding the exercise of that same right as Advocate General Wahl (hereinafter: AG Wahl) analysed in his opinion ${ }^{12}$. The CJEU sided with AG Wahl and held that such a determination is a constitutive condition to the right to be compensated for EU competition law infringement and, due to the direct legal effect of Article 101 TFEU, it must be interpreted uniformly. Therefore, the determination of the entity liable to pay compensation is directly governed by EU law and any national law provisions contrary to EU interpretation cannot be applied ${ }^{13}$.

The practical implication of the CJEU's ruling is that Skanska introduces the specific concept of 'undertaking' used in EU law ${ }^{14}$, to civil liability proceedings before national courts of Member States for EU competition law infringements. In the CJEU's view, using the autonomous concept of undertaking to determine the entity liable to pay compensation for damages due to an infringement of Article 101 TFEU is also in accordance with Directive 2014/104/EU. Under its Article 11(1) Member States must ensure that undertakings which have infringed competition law through joint behaviour are held jointly and severally liable to compensate the parties that suffered a harm because of that infringement and it is for the national legal system of each Member State to determine the entity which is to compensate for that damage. However, the provision of Article 11(1) does not apply to the definition of entities but instead to the attribution of liability between those entities and, thus, the determination of those entities is not subject to

11 Judgment of the Court of 01.12.1998, Case C-326/96 B.S. Levez v T.H. Jennings (Harlow Pools) Ltd, ECLI:EU:C:1998:577; judgement of the COurt of 30.06.2016, Case C-200/14 Silvia Georgiana Câmpean v Serviciul Fiscal Municipal Mediaș, formerly Administrația Finanțelor Publice a Municipiului Mediaș and Administrația Fondului pentru Mediu, ECLI:EU:C:2016:494.

12 Opinion of Advocate General Wahl of 06.02.2019, Case C-724/17 Vantaan kaupunki v Skanska Industrial Solutions Oy, NCC Industry Oy, Asfaltmix Oy, ECLI:EU:C:2019:100, paras 60-66.

13 Case C-724/17, Vantaan kaupunkiv Skanska Industrial Solutions Oy, NCC Industry Oy, Asfaltmix Oy, op. cit., para 28.

14 Jones 2012, p. 301-331; judgment of the Court of 13.06.1962, Case 19/61 Mannesmann AG v High Authority of the European Coal and Steel Community, ECLI:EU:C:1962:31; judgment of the Court of 23.04.1991, Case C-41/90 Klaus Höfner and Fritz Elser v Macrotron GmbH, ECLI:EU:C:1991:161. 
interpretation according to national law provisions of the Member States. Moreover, Article 1 of Directive 2014/104 confirms that those responsible for damage caused by an infringement of EU competition law are specifically the 'undertakings' which committed that infringement ${ }^{15}$. In EU competition law, the notion of undertaking covers any type of economic entity exercising an economic activity, irrespective of its legal status or the way in which it is financed (Hirsch 2008, p. 409-431). As an economic notion, it describes an economic unit irrespective if in law that same economic unit consists of several legal or natural persons (Pietrini 2017, p. 309-342).

Since an 'undertaking' is an autonomous concept of EU law, the CJEU held that it must be interpreted and applied in the same way both in public enforcement of EU competition law under Article 23(2) of Regulation 1/200316 as well as in private enforcement under the provisions of Directive 2014/104/EU. In the CJEU's holistic approach to EU competition law provisions, both public and private enforcement of EU competition law are an integral part of a system intending to punish undertakings' anticompetitive behaviour and to deter them from engaging in such conduct. The maintenance of the system of effective competition could be endangered if the undertakings responsible for compensation for harm caused by an infringement of Article 101 TFEU could escape penalties by changing their legal identity through corporate restructuring and other legal or organisational changes under national laws (Stuyck 2017, p. 177-191). It could also lead to an increase in forum shopping between Member States through the exercise of the freedom of establishment (Mercer, 2013, p. 329-336). For that reason, and in order to guarantee the effectiveness of competition law provisions (Pardolesi 2012, p. 289-310), the CJEU adopted AG Wahl's analysis on the idea that 'liability is attached to assets, rather to a particular legal personality ${ }^{17}$ '. That means practically that the principle of economic continuity, applied to public enforcement of EU competition law in order to impose fines to undertakings, must also be extended in regards to private enforcement of the same legal provisions. The principle of economic continuity ensures that an economic entity which continues its economic activities through legal or organisational corporate changes remains liable for infringing EU competition law provisions, since the initial entity that committed the infringement and its successor can be considered identical from an economic point of view ${ }^{18}$. The CJEU held therefore that it is not contrary to the principle of individual liability under

15 Case C-724/17, Vantaan kaupunki..., paras 33-35.

16 Council Regulation (EC) No 1/2003 of 16.12 .2002 on the implementation of the rules on competition laid down in Articles 81 and 82 of the Treaty, OJ L 1, 4.1.2003, p. 1-25.

17 Opinion of Advocate General Wahl of 06.02.2019, Case C-724/17 Vantaan kaupunki v Skanska Industrial Solutions Oy, NCC Industry Oy, Asfaltmix Oy, op. cit., para 80.

18 Case C-724/17, Vantaan kaupunki..., para 38. 
classical civil law in general, and under Finnish national law provisions more specifically, to impute liability for an infringement to a company which has taken over the company which committed the infringement where the latter has ceased to exist.

\section{Conclusion}

The Skanska ruling can be seen as a creeping harmonisation of national law provisions of Member States regarding civil liability for EU competition law infringements. It addresses questions that where not answered under Directive 2014/104/EU. Using the autonomous concept of 'undertaking' as a criterion to determine the entity liable to compensate the harm caused because of EU competition law infringements, the CJEU reaffirms its economic approach in interpreting competition law provisions within the internal market as well as a holistic view of the objective pursued by both public and private enforcement of competition law provisions. Imposing fines and awarding damages, are part of the same system aiming at both punishment and deterrence of anticompetitive conduct of undertakings. According to this point of view, it is only fair to extent the principle of economic continuity applied when imposing fines to claims for damages. This case law development and the transposition of Directive 2014/104/EU by the Member States can be an opportunity for further harmonisation in matters regarding national civil liability, for example the evaluation and monetization of the harm suffered when awarding damages among the jurisdictions of Member States (Monti 2018, p. 42-61). Even if the facts leading up to the Skanska ruling concerned an infringement of Article 101 TFEU, the same analysis and legal solution should also apply to future cases regarding Article 102 TFEU infringements, as provisions of both articles produce direct legal effects and their effectiveness is also assured by Directive 2014/104/EU and Regulation 1/2003. The undertakings that proceed in good faith to corporate restructuring, especially through cross-border mergers or acquisitions, should also pay attention to possible competition law risks of their predecessors and procced to a firm and solid due diligence of the present and the past state of the target undertaking's conduct before the conclusion of any transaction that could expose them to civil actions for damages in one or even more Member States. 


\section{Literature}

Cortese B. (2014). Piercing the Corporate Veil in EU Competition Law: The Parent Subsidiary Relationship and Antitrust Liability. In B. Cortese (ed.), EU Competition Law: Between Public and Private Enfrocement. Alphen aan den Rijn: Kluwer Law International.

Hirsch G. (2008). Competition Law: European Community Practice and Procedure-Article by Article Commentary. London: Sweet \& Maxwell.

Iannuccelli P. (2014). The European Court of Justice and the Shaping of Private Enforcement of EU Antitrust Law through Preliminary Rulings. In B. Cortese (ed.), EU Competition Law: Between Public and Private Enforcement. Alphen aan den Rijn: Kluwer Law International.

Jones A. (2012). The boundaries of an undertaking in EU Competition Law. European Competition Journal, 8(2).

Mercer H. (2013). Applicable Law in Cross-Border EU Competition Law Actions-Forum Shopping, Mandatory Rules and Public Policy, In M. Danov et alii (eds.), Cross-Border EU Competition Law Actions. Oxford: Hart Publishing.

Monti G. (2018). Liability Issues not Codified by the Damages Directive: How to fil the gaps?. In P.-L. Parcu et alii (eds.), Private Enforcement of EU Competition Law: The Impact of the Damages Directive. Cheltenham: Edward Elgar Publishing.

Pardolesi R. (2012). Private Enforcement of Antitrust Law. In T. Eger, H-B. Schäfer, (eds.) Research Handbook on the Economics of European Union Law. Cheltenham: Edward Elgar Publishing Limited.

Pietrini S. (2017). Le Private Enforcement et le Public Enforcement après la directive 2014/104/UE: des nouvelles synergies pour un nouvel équilibre dans l'application du droit des pratiques anticoncurrentielles? In V. Giacobbo Peyronnel, C. Verdure (eds.), Contentieux du droit de la concurrence de l'Union européenne - Questions d'actualité et perspectives. Bruxelles: Larcier.

Sauter W. (2016). Coherence in EU Competition Law. Oxford: Oxford University Press. Stuyck J. (2017). The Role of Preliminary References in the Uniform Application of EU Competition Law. In A. Almasan, P. Whelan (eds.), The Consistent Application of EU Competition Law: Substantive and Procedural Challenges. Cham: Springer International Publishing.

Wijckmans F., Tuytschaever F. (2 ${ }^{\text {nd }}$ ed. 2011). Vertical Agreements in EU Competition Law. Oxford: Oxford University Press.

Wilman F. (2015). Private Enforcement of EU Law Before National Courts: The EU Legislative Framework. Cheltenham: Edward Elgar Publishing Limited. 